\title{
INFORMATION TECHNOLOGY-BASED LEARNING (Media Development Applications Quizlet on students in MI DDI Seppange Bone)
}

\author{
${ }^{1}$ Dr. Wardana, M.Pd.I., ${ }^{2}$ Dr. St. Zakiah, M.Pd.I, \\ IAIN BONE ${ }^{1,2}$ \\ wardanarusdy638@gmail.com., sittizakiah15@gmail.com
}

\begin{abstract}
Application quizlet is one of media-based learning android application that can be used to a limited extent to the students, that is, their use by teachers who provided the material is in the form of questions relating to the learning and grating exam questions that will be dihadapai by the students of classes VI MI DDI Seppange Bone. Granting of quizlet is done gradually so that absorption to the students can be more rapid and structured. Use of the media learning is very beneficial to students because it can be developed by entering (input) the subject matter in the form of questions that melingupi an important part of the sub a lesson. Quizlet apps is also a means of contracting the message and information learned. As well as the power tTarik learning using information technology is well designed to help learners in the digest and understand the subject matter. On dasarya this research uses Quasi Experimental Research method, by using the subject of research in the form of a group (class). Class VI MI DDI Seppange taken as the population because, this class was considered qualified and already have knowledge about android-based learning, this can be seen from the quizlet diajuan at the time of pre-test. Variables that are revealed in this research is a study of the response against the application of learning to the students 'quizlet klas VI students taught using quizlet and response application of their learning. Next design research is applied in this study is The pre-test - post-test control group design.
\end{abstract}

\section{Keywords: Learning, Information Technology}

\begin{abstract}
Abstrak Aplikasi quizlet merupakan salah satu media pembelajaran berbasis aplikasi android yang dapat digunakan kepada siswa secara terbatas, yaitu, penggunaanya oleh guru yang diberikan materinya berupa pertanyaan-pertanyaan yang berkaitan dengan pembelajaran dan kisi-kisi soal ujian yang akan dihadapai oleh siswa kelas VI MI DDI Seppange Bone. Pemberian quizlet ini dilakukan secara bertahap sehingga penyerapan kepada siswa dapat lebih cepat dan terstruktur. Penggunaan media pembelajaran sangat bermanfaat kepada siswa karena dapat dikembangkan dengan memasukan (input) materi pelajaran dalam bentuk soal-soal yang melingupi bagian penting sub pelajaran. Aplikasi quizlet ini juga merupakan sarana penyalur pesan dan informasi belajar. Dan juga sebagai daya tTarik pembelajaran yang menggunakan teknologi informasi dirancang secara baik untuk membantu peserta didik dalam mencerna dan memahami materi pelajaran. Pada dasarya penelitian ini menggunakan metode Quasi Experimental Research, dengan menggunakan subjek penelitian dalam bentuk kelompok (kelas). Kelas VI MI DDI Seppange yang diambil sebagai populasi karena, kelas ini dianggap cakap dan sudah memiliki pengetahuan tentang pembelajaran berbasis android, hal ini terlihat dari quizlet yang diajuan pada saat pre-test. Variabel yang diungkap dalam penelitian ini adalah respon belajar, terhadap aplikasi quizlet pembelajaran kepada siswa klas VI siswa yang diajar dengan menggunakan aplikasi quizlet dan respon belajarnya. Selanjutnya desain penelitian yang diterapkan dalam penelitian ini adalah The pre-test-posttest control group design.
\end{abstract}

Kata Kunci: Pembelajaran, Teknologi Informasi

\section{Pendahuluan}

Sekarang ini tidak lagi dikenal dengan istilah abad 21, namun dikenal sebagai era milenia 4.0, dan zaman perkembangan teknologi informasikomunikasi (information \& communication technology). Kemajuan teknologi 
informasi dan komunikasi yang begitu pesat menawarkan berbagai kemudahan baru dalam pembelajaran sehingga menyebabkan terjadinya pergeseran orientasi belajar dan penggunaan media belajar yang lebih berkelas (A. Muhson, 2010: 8). Pergeseran ini menuju dari outside-guided menjadi self-guided dan dari knowledge-as-possession menjadi knowledgeas-construction. Lebih dari itu, teknologi ini ternyata turut pula memberikan kontribusi penting dalam memperbarui konsepsi keilmuan yang semula fokus pembelajaran yang hanya sebagai bentuk penyajian dari berbagai macam jenis ilmu dan pengetahuan menjadi pembelajaran yang beriorinetasi pada bimbingan dan pengembangan (learning and development) agar mampu melakukan eksplorasi kelimuan yang mengarah pada pendaya gunaan keilmuan dalam membentuk masyarakat yang kaya dengan pengetahuan (M. Yazdi, 2012: 10-15)

Penggunaan teknologi dalam pembelajaran menjadi hal yang sangat dibutuhkan dewasa ini, baik oleh pengajar ataupun siswa. Pembelajaran berbasis aplikasi sangat dibutuhkan, namun masih banyak Lembaga Pendidikan apalagi guru-guru yang belum memiliki pengetahuan yang memadaisoal ini, ditambah dengan berbagai persoalan yang berkaitan dengan biaya (cost) yang bagi sebagian orang cukup tinggi.

Kemajuan ilmu pengetahuan dan teknologi memiliki pengaruh yang sangat besar dalam berbagai bidang kehidupan manusia. Pendidikan sebagai salah satu bagian yang tidak terpisahkan dari proses pendewasaan manusia tertentu (D. Priyanto, 2009: 92-110). Di sisi lain teknologi memiliki andil yang besar bagi pengembangan ilmu pengetahuan dan teknologi tersebut, namun pendidikan juga perlu memanfaatkan kemajuan ilmu pengetahuan dan teknologi agar mampu mencapai tujuannya secara efektif dan efisien.

Peningkatan mutu pendidikan pada sekolah merupakan suatu tuntutan. Termasuk pada Pendidikan Agama Islam di sekolah. Salah satu aspek peningkatan dalam meningkatkan mutu materi pembelajaran agama Islam termasuk dalam bidang pembelajaran, yang meyangkut pengorganisasian materi, metode, penggunaan media pembelajaran, dan juga evaluasi pendidikan (D. Priyanto, 2009). Pembelajaran pada SD/MI, perlu dirancang dengan standard PAKEM (Pembelajaran Aktif, Kreatif, Efektif, dan 
Menyenangkan) sehingga peserta didik mampu mencurahkan minat dan jiwanya pada aktivitas pembelajaran yang dijalankan.

Dari tuntutan kebutuhan dan prestasi pembelajaran, denga melihat perbandingan di beberapa negara-negara maju, hal tersebut dengan jelas memberikan gambaran bahwa esensi pendidikan atau pembelajaran harus memperhatikan kebermaknaan bagi peserta didik yang dilakukan secara dialogis atau interaktif, yang pada intinya pembelajaran berpusat pada siswa sebagai pebelajar dan pendidik sebagai fasilitator yang memfasilitasi agar terjadi belajar pada peserta didik. Sebagaimana dalam penelitian ini yang bertujuan untuk menggali posisi guru sebagai fasilitator dan pengembangan siswa sebagai eksekutor dalam pembelajaran (S. Haryoko, 2012: 19).

Kemajuan ilmu pengetahuan dan teknologi pembelajaran telah berpengaruh terhadap penggunaan alat-alat bantu mengajar di sekolahsekolah dan lembaga-lembaga pendidikan lainnya. Dewasa ini pembelajaran di sekolah mulai disesuaikan dengan perkembangan teknologi informasi, sehingga terjadi perubahan dan pergeseran paradigma pendidikan (Hujair, 2009: 11).

Kondisi ini mengindikasikan bahwa penggunaan teknologi informasi dalam proses pembelajaran di kelas yang dilakukan oleh guru, menjadi satu kebutuhan penting sekaligus sebagai tuntutan di era milenia ini. Bertujuan untuk meningkatkan efektivitas dan efisiensi pembelajaran, perlu pemikiran agar pembelajaran dikembangkan ke berbagai model pembelajaran yang kreatif dan inovatif. Hal ini perlu dilakukan agar proses pembelajaran tidak terkesan kurang menarik, monoton dan membosankan sehingga akan menghambat terjadinya transfer of knowledge (Eileen Wood, Julie Mueller, Teena Willoughby, Jacqueline Specht \& Ted Deyoung, 2005: 183-206). Oleh karena itu peran media dalam proses pembelajaran menjadi penting karena akan menjadikan proses pembelajaran tersebut menjadi lebih bervariasi dan tidak membosankan.

Pada intinya proses pembelajaran merupakan proses komunikasi atau penyampaian pesan dari pengantar ke penerima, namun pesan ini berbeda dengan pesan-pesan yang diklasifikasikan oleh materi komunikasi lainya. Komunikasi dalam pembelajaran dilakukan dengan koridor-koridor berbeda, 
dengan menggunakan strategi pembelajaran dan akademik, dengan menyertakan pendekatan-pendekatan keilmuan, prosedural, sistimatis dan massif, memiliki tujuan baik kelembagaan maupun menajemen Pendidikan (Robert B. Kozma, 2003: 1-14).

Pesan berupa materi pelajaran yang dituangkan ke dalam simbolsimbol komunikasi baik verbal (kata-kata dan tulisan) maupun nonverbal. Pesan inilah yang akan ditangkap oleh peserta didik sebagai sebuah pengetahuan, Keterampilan maupun nilai-nilai yang dapat digunakan dalam kehidupan sehari-hari. Agar pesan tersebut tersampaikan secara efektif tentu membutuhkan sarana atau media yang memadai. Dalam kenyataannya retensi siswa atau daya tangkap siswa sangat dipengaruhi oleh model aktivitas belajar yang dilakukan guru (W. Purnomo, 2008: 11-14). Siswa hanya dapat menyerap $5 \%$ bahan pembelajaran apabila aktivitas ceramah dilakukan oleh guru dalam membelajarkan siswa.

Sedangkan apabila aktivitas belajar dilakukan dengan teman sebaya, daya retensi siswa mencapai 90\%. Sebagaimana yang dipaparkan Ali Muhsan (2010: 1-10), bahwa tingkat perhatian siswa yang dimulai dari lecturing (mencari materi pembelajaran), kemudian reading sampai teach others: $90 \%$, jelasnya dapat dilihat pada gambar berikut:

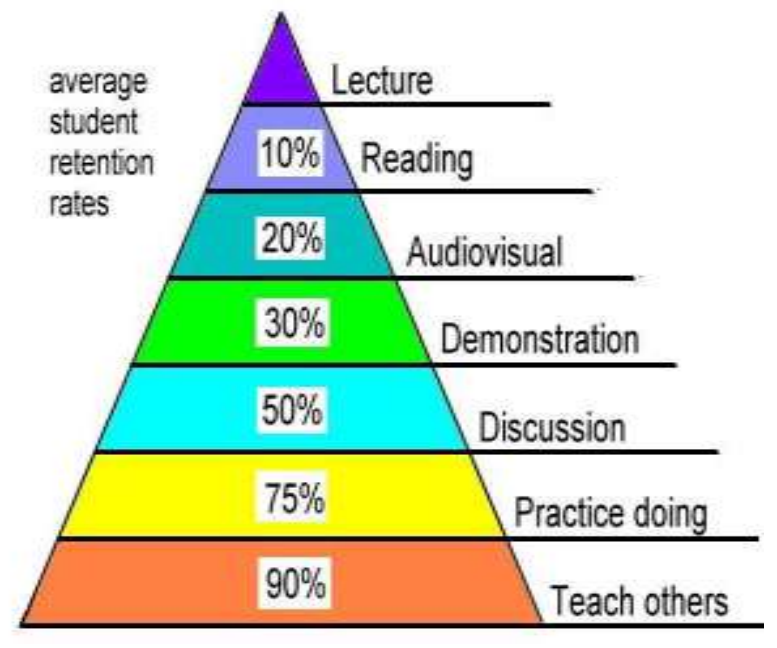

Pembelajaran merupakan
proses terjadinya interaksi
keilmuan antara peserta didik
dengan sumber belajar, namun
proses pembelajaran yang
berlangsung dalam
kenyataannya sebagian besar
masih berpusat pada pengajar,
(teacher center). Proses

pembelajaran yang berkualitas idealnya adalah pembelajaran yang dapat membantu dan memfasilitasi pembelajar untuk mengembangkan potensi dirinya secara optimal, serta mampu mencapai tujuan yang ditetapkan secara 
efektif, dengan berorientasi pada minat, kebutuhan, dan kemampuan pebelajar (C. Ismaniati, 2010: 9-12).

Dalam bidang pendidikan, proses pembelajaran diidentikkan dengan proses penyampaian informasi atau komunikasi. Dalam hal ini media pembelajaran merupakan bagian yang tak terpisahkan pada lembaga pendidikan. Pemanfaatan media pembelajaran merupakan upaya kreatif dan sistematis untuk menciptakan pengalaman yang dapat membelajarkan siswa sehingga pada akhirnya Lembaga pendidikan akan mampu menghasilkan lulusan yang berkualitas.

Penelitian Eyler dan Giles (J. Eyler, 2002: 517-534) membuktikan bahwa keefektifan pembelajaran sangat dipengaruhi oleh media yang digunakan guru. Terlihat bahwa model pembelajaran yang letaknya paling atas dalam kerucut yang diistilahkan dengan lecturing, yakni pembelajaran yang hanya melibatkan symbol-simbol verbal melalui sajian teks adalah pembelajaran yang menghasilkan tingkat abstraksi paling tinggi.

Pembelajaran yang paling efektif adalah pembelajaran yang berada pada dasar kerucut, yakni terlibat langsung dengan pengalaman-pengalaman belajar yang memiliki tujuan. Tingkat abstraksi pada model pembelajaran ini sangat rendah sehingga memudahkan siswa dalam menyerap pengetahuan dan keterampilan baru Ali Muhsan (2010: 1-10) .

Adanya keterbatasan yang melekat pada media konvensional, maka sudah saatnya media konvensional ditingkatkan kualitasnya atau bahkan diganti dengan mengembangkan suatu media pembelajaran yang lebih inovatif sekaligus interaktif, di antaranya adalah media pembelajaran yang dirancang dengan menggunakan bantuan media pembelajaran berbasis teknologi informasi (M. Wijaya, 2012: 20-27). Perkembangan media pembelajaran dengan berbasis komputer sekarang ini dalam aplikasinya sudah menggunakan gabungan beberapa media yang disebut sebagai "multimedia" sehingga pembelajaran menjadi lebih interaktif, efektif, efisien, dan menarik, apalagi didukung dengan penggunaan android dan apliasi pembelajaranya, maka akan menjadi lebih dinamis.

Berdasarkan pentingnya upaya peningkatan kualitas proses pembelajaran maka sangatlah diperlukan adanya upaya pengembangan 
suatu media pembelajaran yang bersifat interaktif berupa model pembelajaran berbasis apliasi, yaitu pembelajaran dengan menggunakan aspek teknologi seperti android dan aplikasi pembelajaran yang tersupport. Mengambil dan menggunakan sisi baik (posisitf) dari android akan menjadikanya sebagai media pembelajaran lebih utama untuk dikenalan kepada siswa sejak dini (S.R. Chandrawati, 2010: 8-14).

\section{Metode Penelitian}

Variabel yang diungkap dalam penelitian ini adalah respon belajar, yaitu respon siswa kelas VI MI DDI Seppange terhadap materi ajar dengan menggunakan aplikasi quizlet media pembelajaran berbasis android. Pemilihan aplikasi quizlet dan membandingkanya dengan respon belajar siswa dengan hanya menggunakan media konvensional. Selanjutnya desain penelitian yang diterapkan dalam penelitian ini adalah The pre-test-post-test control group design (P Dugard, \& J. Todman, 1995: 23).

Ada dua mata pelajaran yang digunakan dalam pembelajaran yang menggunakan aplikasi berbasis android, yaitu mata pelajaran Sejarah Kebudayaan Islam dan Matematika. Kemudian untuk memberikan gambaran yang jelas tentang variabel yang diteliti dalam penelitian dapat diberikan batasan sebagai berikut:

a) Respon belajar siswa yang diajar dengan menggunakan media aplikasi quizlet berbasis android adalah respon siswa yang diperoleh siswa dalam belajar, sehingga indikator pencapaianya adalah pemahaman pertanyaan quiz yang ada pada android, responya dapat positif atau negatif.

b) Respon belajar siswa terhadap aplikasi quizlet, sedangkan tingat pemahaman terhadap materi pembelajaran yang diajarkan dengan menggunakan cara (media) konvensional adalah hasil yang diperoleh siswa berup pemahaman struktural pertanyaan, dalam belajar. Kemudian melihat dan membandingkan dengan pembelajaran menggunakan cara (metode) konvensional. 
c) Populasi dalam penelitian ini adalah keseseluruhan siswa MI DDI Seppange yang berjumlah 35 orang. Jumlah 35 orang ini kemudian dibagi dua kelompok yang diambil melalui teknik random sederhana (simple random sampling). Dengan rincian kelompok A (yang diajar dengan menggunakan media aplikasi quizlet berbasis android) sebanyak 17 orang dan kelompok B (yang diajar dengan menggunakan cara/media quiz konvensional atau teacher center) sebanyak 18 orang. Selanjutnya tahap pelaksanaan eksperimen diawali dengan penerapan pola perlakuan yaitu penggunaan media pembelajaran berbasis android dalam mata pelajaran SKI dan Matemetika.

d) Dalam pelaksanaannya dibagi atas beberapa tahap yang dilakukan yaitu:

(a) Tahap persiapan dengan melakukan observasi di lokasi penelitian (sekolah/kelas VI) setelah mendapat persetujuan dari kepala madrasah dan guru wali kelas, serta guru bidang studi SKI dan Matematika, yang dibagi dalam dua kelompok. Sebelum dilaksanakan proses pembelajaran, terlebih dahulu dipersiapkan satuan pembelajaran yang terdiri dari pokok bahasan, indikator, strategi pembelajaran serta alokasi waktu untuk mata pelajaran tiap-tipa pertemuan memerlukan waktu dan berapa kali pertemuan,

(b) Tahap pelaksanaan, yakni tahap proses pembelajaran yang dilaksanakan dengan menggunakan aplikasi quzlet berbasis android yang terdiri atas empat tahap kegiatan yaitu orientasi latihan, umpan balik pertanyaan, dan lanjutan. Masing-masing kegiatan pada point (b) juga dilaksanakan baik untuk kelompok eksperimen maupun kontrol.

Instrumen dikembangkan berdasarkan silabus dan RPP mata pelajaran SKI dan Matematika, kemudian dijabarkan mulai pokok bahasan sampai sub-pokok bahasan serta indikator-indikator yang akan dicapai. Pola pengembangan tes menggunakan model tes responsif belajar, dimana model soalnya menggunakan pola pilhan ganda dengan 5 opsi (pilihan). Untuk menjamin kualitas dan bobot soal, soal tes dikembangkan dengan model soal analisis, namun dapat mencerminkan kemampuan yang komprehensif dari siswa. Selanjutnya tes awal diberikan sebelum berlangsung proses 
pembelajaran sedangkan tes akhir diberikan setelah berlangsung proses pembelajaran. Respon positif terhadap peningkatan interaksi hasil belajar siswa dihitung dari selisih antara skor akhir dan awal.

Data dianalisis dengan menggunakan teknik statistik deskriptif dan statistik inferensial. Teknik statistik deskriptif digunakan untuk mendeskriptifkan skor siswa baik kelompok ekperimen maupun kelompok kontrol. Sedangkan statistik inferensial digunakan untuk menguji hipotesis yang meliputi uji kesamaan dua rata-rata dengan menerapkan statistik t. untuk keperluan uji hipotesis ini, terlebih dahulu diadakan uji persyaratan analisis yakni: uji normalitas dan uji homogenitas varians. Selanjutnya untuk mengeliminasi kesalahan matematis perhitungan dilakukan dengan menggunakan pengolah data Statistical Package for Social Scince (SPSS) versi 17,0 for windows (Widhiarso, W., \& UGM, F. P. (2012; 1-14).

Selanjutnya untuk mengeliminasi ancaman validitas internal dan ancaman validitas eksternal (Z. Matondang, 2009: 87-97), maka dilakukan hal-hal sebagai berikut:

a) Proses eksperimen dilakukan tidak terlalu lama, yakni sekitar 10 kali pertemuan, hal ini dilakukan untuk mengeliminasi efek pendewasaan,

b) Proses ekperimen dilakukan tidak terlalu dekat (sempit) untuk mengeliminasi efek testing,

c) Anggota kelompok baik kelompok eksperimen (media audio-visual) maupun kelompok kontrol (metode konvesional) dipilih secara ramdom agar tidak terjadi "penggiringan" kelompok ekeperimen adalah kelompok mampu atau sebaliknya, dan

d) Jumlah mahasiswa yang ada semuanya dimasukkan dalam kelompok eksperimen atau kelompok kontrol, untuk menghindari kelompok yang hilang (mortalitas).

Penelitian pada proses pembelajaran ini, secara umum merupakan sebuah upaya mencermati proses pembelajaran yang berjalan, hasil belajar indikatornya tidak hanya dari satu variable prestasi belajar, namun multi variable termasuk respon siswa dan interaksi pembelajaran yang bertumpu pada media belajar. Oleh karena itu, manfaat media dalam proses pembelajaran adalah memperlancar interaksi antara guru dan siswa sehingga 
kegiatan pembelajaran akan lebih efektif dan efisien (R. Susilana, \& C. Riyana, 2008: 2-11). Dalam penelitian ini langkah-langkah yang dilakukan secara metodologis dan perlunya penyesuaian tindakan agar pengambilan data dapat dilakukan secara persuasif dan kredibel serta kompeten dan komparatif, adalah sebagai beriku yaitu:

1. Penyampaian materi pelajaran dapat disesuaikan dengan standar kurikulum (K13).

2. Proses pembelajaran jelas dan menarik

3. Proses pembelajaran interaktif

4. Efisiensi dalam waktu dan tenaga, berapak jam dan berapa kali pertemuan

5. Mencermati rspon belajar siswa

6. Fleksibilitas penggunaan media

7. melihat sikap positif siswa terhadap materi dan proses belajar

8. Perubahan peran guru ke arah yang lebih positif dan produktif.

\section{Hasil Penelitian}

Hasil pengujian hipotesis yang menyatakan bahwa pembelajaran menggunakan aplikasi quizlet sebagai media media pembelajaran berbasis android lebih baik dibanding dengan pembelajaran melalui cara dan pendekatan konvensional. Hal tersebut menunjukkan bahwa perlu ada perubahan paradigma dalam proses pengajaran dan pembelajaran kepada siswa dengan memperhatikan factor interaksi belajar.

Faktor kejenuhan merupakan salah faktor yang tidak terprediksi (unpredictable factor) yang berada di level bawah indikator pencapaian atau peningatan hasil belajar. Kejenuhan ini dapat bermula dari siswa kemudian merambat kepada guru, atau sebaliknya, tergantung mana yang dominan. Secara berantai memberikan efek pada perkembangkan pengajaran kurang begitu diperhatikan, sebagaimana yang dilakukan Fauziyah di Sleman (N. Fauziyah, 2013: 99-108). .

Pola pengajaran konvensional justru masih sangat dominan dikalangan siswa dengan mempertimbangkan berbagai kendala, termasuk jaringan dan data internet. Di samping itu temuan penelitian ini menunjukkan bahwa variasi model pengajaran, khususnya yang melibatkan aplikasi media 
berbasis android sangat cocok untuk model pengajaran interkatif di kelas, seperti penggunaan aplikasi quizlet kepada siswa kelas VI MI DDI Seppange, dikarenakan materi quizlet ini buan hanya berupa jenis pertanyaan atau pernyataan, akan tetapi dapat berupa analisis narasi bergambar dan video bergerak, yang merupakan peristiwa dan kejadian nyata dan factual, yang tingat kesuaranya dirancang secara bertahap, diujikan, diimplementasian dan dikembangkan secara terus menerus. Siswa tidak hanya di bawah ke dalam dunia yang mendekati kenyataan, akan tetapi ke arah progresitas keilmuan yang sesuai dengan kenyataan dalam kehidupanya

\section{Pembahasan}

Seperti telah disebutkan di atas bahwa kelompok eksperimen ditetapkan sebanyak 17 orang siswa (media aplikasi berbasis android) dan kelompok kontrol sebanyak 18 orang siswa (konvensional method). Selanjutnya yang dianalisis masing-masing diambil 12 responden untuk tiaptiap kelompok. Pengambilan dari 17 menjadi 12 maupun dari 18 menjadi 12 diambil secara acak (random). Hasil pre-test, post-test maupun gain skor untuk tiap-tiap kelompok (konvensianal maupun quizlet berbasis aplikasi android) dapat diilustrasikan seperti Tabel di bawah.

\section{Tabel: Data Skor Pre-Test dan Post-Test}

\begin{tabular}{|c|c|c|c|c|c|c|c|c|}
\hline \multirow[t]{2}{*}{ No } & \multirow[t]{2}{*}{$\mathrm{kd}$} & \multicolumn{3}{|c|}{$\begin{array}{c}\text { Kelompok } \\
\text { control/konvensiaon } \\
\text { al }\end{array}$} & \multirow[t]{2}{*}{ No. } & \multicolumn{3}{|c|}{$\begin{array}{c}\text { Kelompok } \\
\text { eksperimen/audio- } \\
\text { visual }\end{array}$} \\
\hline & & Pre-test & $\begin{array}{c}\text { Post- } \\
\text { test }\end{array}$ & $\begin{array}{l}\text { Gain } \\
\text { skor }\end{array}$ & & $\begin{array}{l}\text { Pre- } \\
\text { test }\end{array}$ & $\begin{array}{l}\text { Post } \\
\text { - } \\
\text { test }\end{array}$ & $\begin{array}{l}\text { Gain } \\
\text { skor }\end{array}$ \\
\hline 1 & hs & 70 & 80 & 10 & 1 & 72.5 & 86.5 & 20 \\
\hline 2 & Ir & 67.5 & 72.5 & 5 & 2 & 65 & 80 & 15 \\
\hline 3 & $d r$ & 60 & 80 & 20 & 3 & 70 & 80 & 10 \\
\hline 4 & $\mathrm{mr}$ & 70 & 80 & 10 & 4 & 67.5 & 82.5 & 15 \\
\hline 5 & al & 73 & 80 & 7 & 5 & 72 & 90 & 18 \\
\hline 6 & $\mathrm{ik}$ & 65.5 & 77.5 & 12 & 6 & 75 & 82.0 & 12 \\
\hline 7 & rh & 75 & 85 & 10 & 7 & 72.5 & 92.5 & 15 \\
\hline 8 & sk & 65 & 70 & 5 & 8 & 65 & 85 & 20 \\
\hline 9 & al & 70 & 75 & 5 & 9 & 85 & 90 & 15 \\
\hline 10 & ni & 77 & 85 & 8 & 10 & 85 & 90 & 15 \\
\hline 11 & $\mathrm{fr}$ & 71 & 80 & 9 & 11 & 62.5 & 82.5 & 20 \\
\hline
\end{tabular}




\begin{tabular}{|l|c|c|c|c|c|c|c|c|}
\hline 12 & ns & 65 & 75 & 10 & 12 & 75 & 95 & 20 \\
\hline $\begin{array}{l}\text { Rata } \\
\text { rata }\end{array}$ & & 69.08 & 78.33 & 11.29 & $\begin{array}{c}\text { Rata- } \\
\text { rata }\end{array}$ & 89.33 & $\begin{array}{c}86.0 \\
0\end{array}$ & 16.25 \\
\hline
\end{tabular}

Dari perhitungan statistik deskriptif untuk masing-masing gain skor diperoleh data varians untuk kelompok eksperimen (quizlet aplikasi) diperoleh 16,93, sedangkan untuk varians untuk kelompok kontrol (konvensional) diperoleh 11,29. Data ini selanjutnya diuji, apakah dua kelompok tersebut homogen atau heterogen, maka perlu dilakukan perhitungan dengan formula "Test homogenitas varians", yang dalam perhitunganya sebagai berikut:

\section{Variansi terbesar $F \square$ \\ Variansi terkecil}

Dengan demikian untuk menetapkan apakah variansnya homogen atau heterogen hasil $F$ dihitung dikonsultasikan dengan $F$ tabel. Apabila $F$ hitung lebih kecil dibanding $F$ tabel maka distribusinya homogen. Dalam perhitungan Fhitung<Ftabel $(1,0,49<2,0,82)$. Dengan demikian dapat disimpulkan bahwa distribusi data yang akan dianalisis adalah homogen .

Setelah dilakukan pengujian persyaratan analisis, dan ternyata distribusi datanya normal maka dilanjutkan dengan analisis data dengan menggunakan uji-t, dengan memperbandingkan gain skor antara kelompok ekperimen (quizlet aplikasi) dan kelompok kontrol (konvensional).

Tampilan dari hasil analisis menggunakan SPSS versi 17.0 diperoleh a) rata-rata gain skor kelompok eksperimen $=16,25$; b) rata- rata Gain skor kelompok kontrol $=11,29$; c) Variansi gain skor kelompok. Kemudian eksperimen $\mathrm{S}_{1}{ }^{2}=16,93$, dan d) Variansi gain skor kelompok control $\mathrm{S}_{2}{ }^{2}=$ 11,29. Nilai tersebut apabila dimasukkan melalui formula:

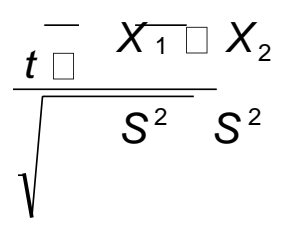




\section{$1-\square \underline{1}$ \\ $n_{1} \quad n_{2}$}

Maka diperoleh :

$$
t=8,46
$$

Selanjutnya untuk memaknai perbandingan tersebut $t$ hitung dibandingkan dengan t tabel dengan $\mathrm{dk}=\mathrm{n}_{1}+\mathrm{n}_{2}-2=12+12-2=22$. $\mathrm{T}$ tabel $=2,017$. jadi, $t$ hitung $>t$ table $=8,046>2,017$. Dengan demikian $t$ hitung $\mathrm{H}_{1}$ diterima dan $\mathrm{H}_{0}$ ditolak. Dengan kata lain terdapat perbedaan yang signifikan kelompok siswa yang di ajar dengan media pembelajaran quizlet aplikasi berbasis android dibandingkan dengan kelompok siswa yang diajar dengan pendekatan konvensional, atau lebih tegasnya siswa yang diajar audio visual lebih baik hasil belajarnya dibanding siswa yang diajar dengan pendekatan konvensional.

Berikut beberapa kesimpulan serat yang dapat diuraikan dalam penelitian pembelajaran ini, sehingga proses pembelajaran dengan menggunakan media tekbnologi informasi android dapat lebih dikembangkan penggunaanya, yaitu sebagai berikut:

1. Media beraplikasi dapat membuat materi pelajaran yang abstrak menjadi lebih konkret

2. Media beraplikasi juga dapat mengatasi kendala keterbatasan ruang dan waktu

3. Media beraplikasi dapat membantu mengatasi keterbatasan indera manusia.

4. Media beraplikasi dapat menyajikan objek pelajaran berupa benda atau peristiwa langka dan berbahaya ke dalam kelas.

5. Informasi pelajaran yang disajikan dengan media yang tepat akan memberikan kesan mendalam dan lebih lama tersimpan pada diri siswa. 
6. Media beraplikasi mengkonkretkan konsep-konsep yang bersifat abstrak, sehingga dapat mengurangi verbalisme. Misalnya dengan menggunakan gambar, skema, grafik, model, dan sebagainya.

7. Media beraplikasi membangkitkan motivasi, sehingga dapat memperbesar perhatian individual siswa untuk seluruh anggota kelompok belajar sebab jalannya pelajaran tidak membosankan dan tidak monoton.

8. Media beraplikasi memfungsikan seluruh indera siswa, sehingga kelemahan dalam salah satu indera (misal: mata atau telinga) dapat diimbangi dengan kekuatan indera lainnya.

9. Media beraplikasi mendekatkan dunia teori/konsep dengan realita yang sukar diperoleh dengan cara-cara lain selain menggunakan media pembelajaran.

10. Media beraplikasi meningkatkan kemungkinan terjadinya interaksi langsung antar siswa dengan lingkungannya. Misalnya dengan menggunakan rekaman, eksperimen, karyawisata, dan sebagainya.

11. Media beraplikasi memberikan uniformitas atau keseragaman dalam pengamatan, sebab daya tangkap setiap siswa akan berbeda-beda tergantung dari pengalaman serta intelegensi masing-masing siswa. Misalnya persepsi tentang persepsi tentang tuhan, nabi, malaikat, syaitan, syurga dan neraka dan benda-benda alam ciptaan tuhan lainya dapat diperoleh uniformitas dalam pengamatan kalau benda itu diamati langsung atau tiruannya saja dibawa ke depan kelas.

12. Media beraplikasi menyajikan informasi belajar secara konsisten dan dapat diulang maupun disimpan menurut kebutuhan. Misalnya berupa rekaman, film, slide, gambar, foto, modul, dan sebagainya.

\section{Kesimpulan}

Jenis penelitian ini adalah penelitian Quasi-eksperimen yang dilaksanakan pada siswa MI DDI Seppange Kecamatan Bengo Kabupaten Bone. Proses pembelajaran yang dilakukan dengan menggunakan metode konvensional dan penggunaan aplikasi quizlet berbasis android aplikasi belajar, pada kelas VI MI DDI Seppange, pada mata pelajaran SKI dan Matematika, pendekatan yang digunakan adalah komparasi implikatif terhadap respon belajar siswa, yang terbagi pada 2 kelompok, A (terdiri 17 
siswa), kelompo A menggunakan metode konvensional dan B (terdiri 18 siswa), menggunakan media quizlet aplikasi pembelajaran berbasis android

Berdasarkan hasil analisis dan pengujian hipotesis, dapat ditarik kesimpulan sebagai berikut: 1.respon belajar siswa elas VI, untuk kelompok A dengan menggunakan metode/cara konvensional (kelompok kontrol) menunjukkan rata-rata pre-test. Sehingga diperoleh Efektivitas Pemanfatan Media $\ldots .9=69,08$, post-test $=78,33$, dan rata-rata gain skor $=11,29$. Sedangkan respon belajar siswa kelas VI MI dengan menggunakan media aplikasi quizlet (kelompok eksperimen) menunjukkan rata-rata pre-test = 89,33 , post-test $=86,00$, dan rata-rata gain skor $=16,25$. 2 . Respon belajar siswa yang diajar dengan menggunakan quizlet sebagai media belajar berbasis aplikasi android, memiliki skor yang jauh lebih tinggi dibanding dengan siswa yang diajar menggunakan pendekatan konvensional. Hal ini dapat ditunjukkan pada hasil post-test antara kelompok eksperimen (quizlet aplikasi) $=86,00$, dan kelompok kontrol (konvensional) $=78,33$, dengan hasil pres-test kedua kelompok tersebut hampir sama. Apabila diperhitungkan skor pre-test, dengan memperbandingkan gain skor juga menunjukkan perbedaan yang signifikan antara gain skor kelompok kontrol dengan kelompok eksperimen, dimana menunjukkan nilai t hitung $=8,46$, dengan t tabel $=2,07$, sehingga t hitung > t tabel pada signifikansi $5 \%$.

\section{Saran}

Saran Berdasarkan kesimpulan di atas, maka dapat disarankan sebagai berikut:

1. Kepada guru-guru di MI DDI Seppange, dan guru-guru pada umumnya disarankan dapat memulai menggunakan model pembelajaran quizlet aplikasi berbasis android yang ternyata dapat lebih meningkatkan gairah belajar mahasiswa, dan pada gilirannya akan dapat meningkatkan respon belajar yang nantinya mengarah kepada peningkatan hasil belajar siswa.

2. Bagi instansi-instansi (lembaga) pendidikan, utamanya pemerintah yang berhak dan bertanggung jawab atas kemajuan dan perkembangan Pendidikan, serta para pemerhati pendidikan termasuk Perguruan Tinggi sudah saatnya mengembangkan atau membuat regulasi perkuliahan yang 
mewajibkan para dosen dalam penggunaan media audio visual dalam meningkatkan efektivitas pembelajaran.

3. Memperkaya proses pembelajaran dengan banyak menggunakan teknologi pembelajaran. Memperkaya model pembelajaran dengan mengoptimalkan teknologi di dunia pendidikan pada umumnya dan domain pembelajaran pada khususnya.

\section{DAFTAR PUSTAKA}

[1] Chandrawati, S. R. (2010). Pemamfaatan E-learning dalam Pembelajaran. Jurnal Cakrawala Kependidikan, 8, (2).

[2] Dugard, P., \& Todman, J. (1995). Analysis of pre-test-post-test control group designs in educational research. Educational Psychology, 15(2)

[3] Eileen Wood, Julie Mueller, Teena Willoughby, Jacqueline Specht \& Ted Deyoung (2005) Teachers' Perceptions: barriers and supports to using technology in the classroom, Education, Communication \& Information, 5:2, , DOI: $\underline{10.1080 / 14636310500186214}$

[4] Eyler, J. (2002). Reflection: Linking service and learning —Linking students and communities. Journal of social issues, 58(3).

[5] Fauziyah, N. (2013). Faktor Penyebab Kejenuhan Belajar Sejarah Kebudayaan Islam (SKI) pada Siswa Kelas XI Jurusan Keagamaan di MAN Tempel Sleman. Jurnal Pendidikan Agama Islam UIN Sunan Kalijaga, 14(1).

[6] Haryoko, S. (2012). Efektivitas pemanfaatan media audio-visual sebagai alternatif optimalisasi model pembelajaran. Jurnal Edukasi Elektro, 5(1).

[7] Ismaniati, C. (2010). Penggunaan teknologi informasi dan komunikasi dalam peningkatan kualitas pembelajaran. Yogyakarta: Universitas Negeri Yogyakarta.

[8] Matondang, Z. (2009). Validitas dan reliabilitas suatu instrumen penelitian. Jurnal Tabularasa, 6(1).

[9] Muhson, A. (2010). Pengembangan media pembelajaran berbasis teknologi informasi. Jurnal Pendidikan Akuntansi Indonesia, 8(2).

[10] Nurdyansyah, N. (2017). Sumber Daya dalam Teknologi Pendidikan. Universitas Muhammadiyah Sidoarjo.. https://scholar.google.co.id/

[11] Priyanto, D. (2009). Pengembangan Multimedia Pembelajaran Berbasis Komputer. Insania, 14(1).

[12] Priyanto, D. (2009). Pengembangan Multimedia Pembelajaran Berbasis Komputer. Insania, 14(1). 
[13] Robert B. Kozma (2003) Technology and Classroom Practices, Journal of Research on Technology in Education, 36:1, DOI: $\underline{10.1080 / 15391523.2003 .10782399}$

[14] Susilana, R., Si, M., \& Riyana, C. (2008). Media pembelajaran: hakikat, pengembangan, pemanfaatan, dan penilaian. CV. Wacana Prima.

[15] Widhiarso, W., \& UGM, F. P. (2012). Tanya jawab tentang uji normalitas. Fakultas Psikologi UGM (diakses pada 7 Desember 2016).

[16] Wijaya, M. (2012). Pengembangan model pembelajaran e-learning berbasis web dengan prinsip e-Pedagogy dalam meningkatkan hasil belajar. Jurnal Pendidikan Penabur, 11(19).

[18] Yazdi, M. (2012). E-learning Sebagai Media Pembelajaran InteraktifBerbasis Teknologi Informasi. In FORISTEK: Forum Teknik Elektro dan Teknologi Informasi (Vol. 2, No. 1). 